\title{
Systemic calprotectin and chronic inflammatory rheumatic diseases
}

Xavier Romand ${ }^{A^{*}}$, Chloé Bernardy ${ }^{A^{*}}$, Minh Vu Chuong Nguyen ${ }^{A, B}$, Anaïs Courtier ${ }^{B}$, Candice Trocme $^{C, D}$, Margot Clapasson ${ }^{A}$, Marie-Hélène Paclet ${ }^{A, D}$, Bertrand Toussaint ${ }^{C, D}$, Philippe Gaudin $^{A, B}$, Athan Baillet ${ }^{A, B}$

${ }^{a}$ GREPI, EA 7408, University Grenoble Alpes, 38700 La Tronche, France

${ }^{\mathrm{b}}$ Sinnovial SAS, Avenue de Kimberley, 38130 Échirolles, France

'TIMC-IMAG Laboratory UMR 5525, CNRS, University Grenoble Alpes, 38041 Grenoble , France.

${ }^{d}$ Centre Hospitalier Universitaire Grenoble Alpes, Hôpital Michallon Pôle Biologie, Laboratoire de Biochimie des Enzymes et des Protéines, 38700 La Tronche, France

* both authors equally contributed to this work

Corresponding author: Chloé Bernardy, Univ. Grenoble Alpes, GREPI, EA 7408, University Grenoble Alpes, La Tronche 38700, France. cbernardy@chu-grenoble.fr. +33628735836 


\section{ABSTRACT}

Calprotectin is a calcium binding protein produced by neutrophils and monocytes locally at the site of inflammation in order to trigger the innate immunity receptors. This unique characteristic makes it a good proxy for evaluation of local inflammation in chronic inflammatory rheumatic diseases.

Complete data suggest, in inflammatory rheumatic diseases, a relevant role of calprotectin in the inflammatory process. The interest of serum or plasma calprotectin dosage has been studied intensively, in the current years, especially in rheumatoid arthritis, spondyloarthritis, juvenile idiopathic arthritis and ANCA associated vasculitis. Calprotectin seems to be a great candidate as biomarker to assess and monitor disease activity, to predict structural progression or response to the treatment. Calprotectin showed its ability to predict radiological progression in rheumatoid arthritis and ankylosing spondylitis. Serum calprotectin can predict the risk of relapse in ANCA associated vasculitis and the risk of inflammatory bowel disease in spondyloarthritis. Nevertheless, studies report controversial result requiring replication in other large cohort. The lack of assay standardization between studies is a problem to replicate and compare studies. In this review, we discuss on the interest of systemic calprotectin in chronic inflammatory rheumatic disease as a diagnostic, activity or prognostic biomarker.

Key words: calprotectin; biomarker; chronic inflammatory rheumatic diseases 


\section{Introduction}

Calprotectin (S100A8/A9 or Myeloid Related Protein 8/14) is predominantly expressed by myelomonocytic cells(1), namely monocytes and neutrophils but also in early differentiation stages of macrophage(2). This protein constitutes, respectively, $40 \%$ and $5 \%$ of the polymorphonuclear neutrophil cytosolic and monocytes protein content. Calprotectin is an alarmin with important proinflammatory properties mainly secreted by activated neutrophils in a calcium-dependant manner. It is an heterodimeric complex of S100A8 and S100A9 proteins, which are calcium-binding protein with EF hand calcium domains(3), constituting the physiologically active conformation of this protein. Beside calcium concentration and posttranslational modifications such as phosphorylation or nitrosylation influences calprotectin quaternary structure, and therefore its physiological functions(4). Extracellular calprotectin induces, in particular via binding to Toll like receptor 4 (TLR-4) and Receptor of Advanced Glycation Endproducts (RAGE), a pro-inflammatory response in monocytes/macrophages, neutrophils, lymphocytes and endothelial cell(5). The C-terminal tail of S100A9 represents the region to which carboxyl groups of fatty acid bind. Hence, calprotectin is a unique arachidonic acid reservoir with a potential impact on prostanoids production by the modulation of cyclooxygenases activity.

Calprotectin plays an important role in inflammation as it triggers the innate immunity receptors(5). Hence, calprotectin was identified as a marker of Rheumatoid Arthritis (RA) in the synovial fluid, with synovial concentration differentiating RA from other rheumatic diseases(6). Growing body of evidence suggests a role for calprotectin in several Chronic Inflammatory Rheumatic Disorders such as juvenile chronic arthritis (7)RA(8), Behcet disease (9) and ANCA-associated vasculitis (AAV)(10). Several assays are available to measure calprotectin levels such as ELISA, immunochromatography and immunoturbidimetry(11). At the moment, no guideline indicates the technique which should be used to estimate calprotectin level.

\section{Calprotectin (s100 a8/a9 protein) and inflammatory conditions}

\subsection{Calprotectin is a danger signal increased upon neutrophil activation}

Calprotectin has a critical role in inflammation as it can activate the innate immunity pathway sensed by RAGE or TLR. Calprotectin is released when phagocytes are activated in a calcium-dependant manner. Neutrophils release calprotectin when interaction between monocyte and activated endothelium under inflammatory conditions(3) which leads to calprotectin deposit onto the endothelium cells. S100A9 subunit interacts with endothelial cell through heparan sulfate proteoglycans. Calprotectin also recognizes carboxylated N-glycans expressed on inflammatory activated endothelial cells. These mechanisms favor leucocyte extravasation(5). Calprotectin exerts 
paracrine and autocrine effects(12). Calprotectin activates TLR-4 in myeloid cells. Ligation of TLR4 by calprotectin induces wide-ranging effects on neutrophils including cytokines, matrix metalloproteinases, chemokine production and generation of reactive oxygen species.

\subsection{Calprotectin enhances neutrophil oxidative burst}

S100A8 and S100A9 were recently introduced as partners for phagocyte NADPH oxidase regulation. They potentiate NADPH oxidase activation as positive allosteric effectors; but they also induce the change of cytochrome $b_{558}$ conformation that initiates its activation(12).

In vitro studies suggested that S100A8 and S100A9 combine into various dimers; either homodimers or tetramers, depending of calcium concentrations. Stimulation of neutrophils by calprotectin activates NAPDH oxidase activity and increases reactive oxygen species (Figure 1).

\subsection{Calprotectin modulate adaptive immune system}

A cross-talk between neutrophils and T cells has been identified. Neutrophils - T cells co-culture showed that, in non-inflammatory conditions, neutrophils mainly modulate T-Cell activity through direct contact. But, a soluble factor, calprotectin, was also identified as a factor involved in suppression of T cell proliferation(13). Furthermore, calprotectin skew T cell polarization towards a Th17 polarization. An in vitro study showed that S100A8 has a crucial role in stimulating IL-6 expression by RA synoviocytes, and subsequently promotes Th17 differentiation(14), suggesting that neutralizing calprotectin level in RA synovium may be an effective therapeutic strategy.

\subsection{Ectopic calprotectin production upon inflammatory condition trigger endothelial dysfunction}

Calprotectin is also expressed by other cell types upon inflammatory conditions such as keratinocytes in psoriasis(15) and synovial fibroblast in $\mathrm{RA}(16)$, suggesting a central role of calprotectin in transendothelial migration of leukocytes in psoriatic arthritis (PsA) and RA.

Calprotectin directly induces a distinct inflammatory, thrombogenic response in microvascular endothelial cells. The inflammatory response is characterized by the secretion of inflammatory cytokines, chemokines, and adhesion molecules and by increased vascular permeability(6). 
Calprotectin exerts potent cytotoxic activities by inducing apoptotic and necrotic alterations in endothelial cells(7).

Calprotectin is likely secreted in vessels calcification as neutrophils colonize atheroma plaque. Calprotectin level raised locally in acute myocardial infarction, with an optimal cut off value of 8 $\mathrm{mg} / \mathrm{ml}$ to identify acute myocardial infarction within 3hours (9).

\section{Rheumatoid arthritis}

\subsection{Disease activity}

In most of the trials in early and established RA, calprotectin correlates significantly with inflammatory markers and disease activity score (Table 1). This correlation is often statistically significant and clinically relevant. In a systematic literature review of 17 studies including a total of 1065 patients enrolled, calprotectin levels were high in active disease and were particularly high in rheumatoid factor-positive patients (17)with a significant drop upon treatment. Surrogate markers of subclinical inflammation are currently sought to improve tight control of the disease. Some authors suggested that calprotectin could represent a proxy for local or subclinical inflammation as a correlation between baseline calprotectin levels and Ultrasonography (US) Power Doppler (PD) was found(18).

\subsection{Structural progression and ultrasonography activity}

Baseline calprotectin levels is correlated with Van der Heijde modified Sharp score (SHS) progression. This correlation was independent of age, gender, Clinical Disease Activity Index (CDAI), Erythrocyte Sedimentation Rate (ESR), C-reactive protein (CRP) levels and Rheumatoid Factor positivity $(8,19)$. Jonsson et al. showed that calprotectin is a better predictor of structural progression than ESR or CRP(20). However, in most of trials evaluating calprotectin as a biomarker for structural damages in $\mathrm{RA}$, some of the independent major predictors of structural evolution, such as anti-citrullinated protein antibodies (ACPA) and baseline erosion, was overlooked. In our assay of calprotectin blood levels in the ESPOIR cohort (21)of early RA, suggested CRP, ACPA, Disease Modifying Anti-Rheumatic Drugs (DMARD) treatment and calprotectin were significantly associated with structural evolution in the univariate analysis. When baseline erosion was removed from the multivariate analysis, calprotectin was the only predictor of the structural evolution over 3 years. When the presence of baseline typical erosion was combined in the multivariate Cox Model, calprotectin was not an independent predictor of structural evolution anymore.

In a large Scandinavian RA cohort, calprotectin was significantly correlated with B-mode synovitis ( $r$ = $0.379, p<0.001)$ and PD synovitis scores $(r=0.419, p<0.001)$. The multivariate regression analysis 
showed that calprotectin is a better predictor of the CDAl and synovitis than CRP(22). Similarly, calprotectin had the strongest and most consistent associations with clinical variables and US sum scores in correlation analyses at baseline, among IL-6, S100A12, CRP and ESR(23). Calprotectin positively correlated with PDUS synovitis in RA and PSA patients in clinical remission or with low disease activity in a cross-sectional study of 92 patients treated with adalimumab and etanercept(24).

\subsection{Prediction of clinical response}

In a study published in 2016 based on 87 patients, baseline blood level of calprotectin was significantly different between responders and non-responders to methotrexate $(23.99 \mu \mathrm{g} / \mathrm{ml}, 95 \% \mathrm{Cl}$ [15.39-42.75] versus $9.58 \mu \mathrm{g} / \mathrm{ml}, 95 \% \mathrm{Cl}$ [6.11-24.93], $\mathrm{p}=0.0025)$ with an Area Under the Curve (AUC) of $0.705(95 \% \mathrm{Cl}$ [0.549-0.862]), a sensitivity of $79 \%$ and a specificity of $69 \%$ at a threshold of $13.70 \mu \mathrm{g} / \mathrm{ml}(25)$. In another prospective cohort of patient with RA there was no significant difference between calprotectin baseline level in responders and non-responders to methotrexate (23)(Table 2).

Many studies have investigated the predictive value of calprotectin for clinical response to bDMARD (biologic Disease Modifying Anti-Rheumatic Drugs) with conflicting results. Several studies showed calprotectin as an independent predictive marker of good response to anti-TNF alpha(26,27). Choi et al. showed a predictive value of calprotectin at baseline with adalimumab (OR 3.30, 95\% $\mathrm{Cl}$ [1.14 to 9.60], $\mathrm{p}=0.028$ ), infliximab (OR $9.75,95 \% \mathrm{Cl}$ [1.93 to 49.33], $\mathrm{p}=0.006)$ and rituximab (OR 55, $95 \% \mathrm{Cl}$ [4.30 to 703.43], $p=0.002)(27)$. Another prospective study showed some predictive value of calprotectin for clinical response of adalimumab or etanercept treatment although the multivariate analysis did not include DAS28-CRP(28). A decrease of calprotectin within the first month of treatment with bDMARD was predictive of both EULAR response and decreased sum PD scores(23). However, in a large Caucasian cohort of RA patients, there was no evidence that calprotectin is predictive of EULAR response to etanercept(29). Obry et al. showed that S100A9 subunit predicts response to etanercept, with $83 \%$ sensitivity and $70 \%$ specificity at the threshold of $2.59 \mathrm{ng} / \mathrm{ml}$ whereas calprotectin did not(26).

\section{Spondyloarthritis}

\subsection{Diagnosis}

Magnetic resonance imaging (MRI) is the most sensitive imaging test to detect early SpA and thus helps to limit diagnostic wandering(30). Moreover, Assessment of SpondyloArthritis international 
Society (ASAS) classification criteria include, in addition to radiographic sacroiliac joints, active sacroiliitis on MRI as a diagnostic criterion for axial SpA. However, sacroiliac joint bone marrow oedema is not only specific of SpA but can be found in other disorders responsible for chronic low back pain such as sacroiliac joints degenerative diseases, as well as in healthy subjects(31). The prevalence of sacroiliac joint degenerative diseases is probably underestimated(32). The definition of a positive MRI for spondyloarthritis remains controversial adding complexity to the SpA diagnosis. Other biomarkers are probably necessary to facilitate the diagnosis. C-reactive protein (CRP), a systemic inflammation biomarker, is a criterion included in the ASAS criteria. However, about half of SpA patients have normal CRP levels (33) limiting the interest of this biomarker for the diagnosis.

Serum calprotectin could reflect the local activation of inflammatory innate immune cells involved in enthesitis and arthritis. Over 20 years ago, Hammer et al. described calprotectin as a marker of inflammation and treatment response in reactive arthritis(34). Calprotectin serum levels are significantly increased in axSpA (axial Spondyloarthritis) fulfilling ASAS criteria or AS (Ankylosing Spondylitis) (9,35-39)versus healthy control or with early inflammatory back pain (40) not fulfilling axial SpA ASAS criteria whereas CRP levels could be normal. Nevertheless, calprotectin is not helpful to discriminate early axSpA from nonspecific inflammatory back pain with a sensitivity of $10.0 \%$, a specificity of $90 \%$ and a Positive Predictive Value (PPV) of $38.7 \%$ for a threshold of $412.40 \mathrm{ng} / \mathrm{mL}(40)$. In another cross-sectional study, a serum calprotectin level over $0.9 \mathrm{mg} / \mathrm{L}$ display a sensitivity of $95.3 \%$, a specificity of $82.2 \%$, a positive likelihood ratio (LR) of 5.35 and a negative LR of 0.057 for the diagnosis of chronic inflammatory rheumatic diseases including patients with RA, SpA, PsA and healthy controls(41).

Subsequently, calprotectin was found to be elevated in the feces of patients with SpA. In patient with inflammatory bowel disease, especially with ulcerative colitis, fecal calprotectin level is correlated with clinical activity and endoscopic lesion(42). Serum calprotectin independently predicts a diagnosis of inflammatory bowel disease with sensitivity of 0.69 , a specificity of 0.90 and a positive LR of 7.06 at the threshold of $>852 \mathrm{ng} / \mathrm{ml}$. With a combination of biomarker, especially CRP or albumin, the positive LR grow to 24.14. Another predictive model using CRP, serum and fecal calprotectin level detects microscopic bowel inflammation in SpA patients with an AUC of $74.4 \%$ (0.639-0.849\%, $\mathrm{p}<0.001)(35)$. Predictive model including serum calprotectin could be an interesting tool to determine patient with a high risk of inflammatory bowel disease in SpA. The validation of these predictive models must be replicate in other large cohorts. However, serum calprotectin didn't always correlate with fecal calprotectin (43)suggesting that serum calprotectin derived predominantly from circulating neutrophils, and not from the neutrophil infiltration in the gut. 


\subsection{Disease activity}

Serum levels of calprotectin are also highly significantly increased in axial SpA and AS. Treatment with anti-TNF and anti-IL-17A agents significantly decrease calprotectin levels $(44,45)$. The correlation between serum calprotectin and disease activity seems to be weaker than in RA (Table 3). However, one might emphasize the wide broad of median levels of serum calprotectin in studies evaluating calprotectin as a proxy for Disease activity with discordant results (Table 4). A possible explanation for such heterogeneity in calprotectin levels in SpA cohorts, besides concerns raised on internal reproducibility of calprotectin assays, is a variable gut production of calprotectin which depends on subclinical gut inflammation and inflammatory bowel disease associated with SpA.

\subsection{Structural progression}

Baseline calprotectin serum levels was found to be significantly higher in AS patients with radiologic spinal progression at 2 years assessed with modified Stoke Ankylosing Spondylitis Spinal Score (mSASSS) (table 4). Serum calprotectin in this study could predict the mSASSS worsening by $\geq 2$ units at 2 years with a threshold of $>0.5 \mu \mathrm{g} / \mathrm{mL}$ with a sensitivity of $80 \%$, a specificity of $62 \%$ and an Odds ratio (OR) of 6.2 (95\% Cl 1.6-24.2). Calprotectin in PsA was associated with presence of peripheral radiographic damage (46)but did not perform better than traditional biomarkers to assess the disease activity.

\section{Juvenile idiopathic arthritis}

In patients with polyarticular juvenile arthritis, calprotectin was much higher in synovial fluid than in serum (42 $800 \mathrm{mg} / \mathrm{L}$ versus $2060 \mathrm{mg} / \mathrm{L}$ ) and significantly decreased after intraarticular triamcinolone therapy, suggesting that serum levels of this biomarkers is determined by joint production of calprotectin by myeloid cells(7). Concentrations of calprotectin in serum displayed a strong correlation with disease activity. The exceptionally high serum levels of calprotectin in active systemic-onset juvenile arthritis suggests that calprotectin may be a marker for monitoring disease activity and response to treatment(47).

Despite correlation between calprotectin levels and disease activity in juvenile idiopathic arthritis $(7,47)$, calprotectin could not predict Macrophage Activation Syndrome, which is a lifethreatening complication the systemic form of the disease. A higher rate of calprotectin has been found in patient with juvenile arthritis in terms of response to methotrexate(48). Remarkably serum 
levels of calprotectin were significantly higher in patients who subsequently developed flares than in patients with stable remission(17).

\section{Anca associated vasculitis (aav)}

\subsection{AAV disease mechanisms and calprotectin}

Granulomatosis with polyangiitis (GPA) and microscopic polyangitis (MPA) are severe conditions that share the features of necrositing vasculitis of small vessels in multiple organ systems and characteristic autoantibodies anti-neutrophil cytoplasmic antibodies (ANCAs) and thus can be described together as $A A V(10)$.

ANCA activate neutrophils and monocyte in vivo (49)inducing a calprotectin release. In inflammatory tissue, calprotectin is deposited onto the endothelium cells. Besides apoptosis, neutrophil may display another cell death program leads to the production of extracellular traps (NETs) which are highly immunogenic triggering adaptive immune response leading to ANCA formation(50). Previous investigations showed the presence of calprotectin in NET and the antimicrobial activity of calprotectin(51). In vivo, calprotectin is partly bound to NETs(52). Although no ANCA were detected against calprotectin(53). In renal biopsy of patient with AAV, calprotectin was found in glomerular lesions with endocapillary proliferation whereas chronic sclerotic lesions are generally negative (54). Calprotectin plays a crucial role in the development of glomerulonephritis by exerting a proinflammatory effect on macrophages, intrinsic renal endothelial and mesangial cells(55). Patient with AAV have elevated levels of cell surface calprotectin on neutrophils and monocytes and the level of expression increase with the activity of the vasculitis(54). This biomarker may help to manage the treatment in AAV because the course of disease after initial treatment is highly variable with frequently relapse. The monitoring of the disease by a biomarker could avoid an overtreatment with its risk of side effects.

\subsection{Disease activity, relapse and response to treatment}

Serum calprotectin correlate weakly with $\operatorname{CRP}(r=0.22, p=0.016)$, total white cell count $(r=0.23$, $\mathrm{p}=0.01)$ and Birmingham Vasculitis Activity Score (BVAS) score $(r=0.27, p=0.02)(56)$. Pepper et al. (54)have shown that calprotectin levels at 1 or 6 months could predict future relapses, with a sensitivity of $78.6 \%$, a specificity of $92.3 \%$ and a likelihood ratio of 10.3 at a threshold of $>626 \mathrm{ng} / \mathrm{ml}$ at 1 month and a sensitivity of $78.6 \%$ and specificity of $92.3 \%$ at a threshold of $>454 \mathrm{ng} / \mathrm{ml}$ at 6 months, suggesting a relationship both statistically significant and clinically relevant. Calprotectin seems significantly better in the prediction of relapses than ANCA titer rising(54). In the PR3-ANCA patient of RAVE (Rituximab versus Cyclophosphamide for ANCA-associated Vasculitis) trial, the 
increase in ANCA at month 2 of the induction treatment compared to baseline was not associated with the risk of a future relapse (hazard ratio $(\mathrm{HR})=0.85(95 \% \mathrm{Cl}[0.55-1.13])$ whereas the increase in serum calprotectin was significantly associated (HR=2.2, 95\% $\mathrm{Cl}[1.17-4.26])(56)$. Hence, calprotectin could be a help to identify patients requiring more intensive or prolonged induction treatment(56).

\section{Area of uncertainty}

These data support a relevant role of calprotectin as a key molecule of inflammation, which could play a role in structural immunological disorders and tissue damage in chronic inflammatory rheumatic diseases. This protein is released locally in inflammatory joints in contrast with CRP, which is produced by hepatocyte. Contrary to CRP which reflects systemic inflammation in response to local production of IL-6(57), calprotectin seems to be a good proxy for neutrophil activation in a biological fluid. Therefore its measurement is of particular interest within a biological fluid "closed to" the inflammation site such as synovial fluid in $\mathrm{RA}(6)$ and serum in $\mathrm{AAV}(56)$. Calprotectin showed its ability to predict radiological progression in RA and AS. Serum calprotectin can predict the risk of relapse in AAV and in association with other biomarkers, the risk of inflammatory bowel disease in spondyloarthritis. However, it is necessary to replicate these data in other large cohort to confirm these results. Researchers should be aware of the lack of the assay standardization, especially in the context of SpA studies, as shown in Table 2. Some ELISA kits are design for research use only whereas some are approved for in vitro diagnosis. Calprotectin might be of valuable interest to monitor and predict the evolution of chronic inflammatory rheumatic diseases, especially in a predictive model including multiple biomarkers. Better standardization of the assays is nevertheless necessary in order to be able to compare the studies and to have stronger conclusions.

Acknowledgement: The authors thank Sylvie Papacatzis for her help in the study.

\section{Disclosure of interest}

The authors declare that they have no competing interest.

Funding: None 


\section{References}

1. Edgeworth J, Gorman M, Bennett R, Freemont P, Hogg N. Identification of $\mathrm{p8,14}$ as a highly abundant heterodimeric calcium binding protein complex of myeloid cells. J Biol Chem. 1991;266(12):7706国13.

2. Odink K, Cerletti N, Brüggen J, Clerc RG, Tarcsay L, Zwadlo G, et al. Two calcium-binding proteins in infiltrate macrophages of rheumatoid arthritis. Nature. 1987;330(6143):80]2.

3. Korndörfer IP, Brueckner F, Skerra A. The crystal structure of the human (S100A8/S100A9)2 heterotetramer, calprotectin, illustrates how conformational changes of interacting alphahelices can determine specific association of two EF-hand proteins. J Mol Biol. 2007;370(5):887?98.

4. Lim SY, Raftery MJ, Geczy CL. Oxidative modifications of DAMPs suppress inflammation: the case for S100A8 and S100A9. Antioxid Redox Signal. 2011;15(8):2235国8.

5. Rahman MT, Myles A, Gaur P, Misra R, Aggarwal A. TLR4 endogenous ligand MRP8/14 level in enthesitis-related arthritis and its association with disease activity and TLR4 expression. Rheumatol Oxf Engl. 2014;53(2):270?].

6. Baillet A, Trocmé C, Berthier S, Arlotto M, Grange L, Chenau J, et al. Synovial fluid proteomic fingerprint: S100A8, S100A9 and S100A12 proteins discriminate rheumatoid arthritis from other inflammatory joint diseases. Rheumatol Oxf Engl. 2010;49(4):671?82.

7. Frosch M, Strey A, Vogl T, Wulffraat NM, Kuis W, Sunderkötter C, et al. Myeloid-related proteins 8 and 14 are specifically secreted during interaction of phagocytes and activated endothelium and are useful markers for monitoring disease activity in pauciarticular-onset juvenile rheumatoid arthritis. Arthritis Rheum. 2000;43(3):628?37.

8. Hammer HB, Odegard S, Fagerhol MK, Landewé R, van der Heijde D, Uhlig T, et al. Calprotectin (a major leucocyte protein) is strongly and independently correlated with joint inflammation and damage in rheumatoid arthritis. Ann Rheum Dis. 2007;66(8):1093?7.

9. Oktayoglu P, Bozkurt M, Mete N, Caglayan M, Em S, Nas K. Elevated serum levels of calprotectin (myeloid-related protein 8/14) in patients with ankylosing spondylitis and its association with disease activity and quality of life. J Investig Med Off Publ Am Fed Clin Res. 2014;62(6):880? 4 .

10. Thai L-H, Charles P, Resche-Rigon M, Desseaux K, Guillevin L. Are anti-proteinase-3 ANCA a useful marker of granulomatosis with polyangiitis (Wegener's) relapses? Results of a retrospective study on 126 patients. Autoimmun Rev. 2014;13(3):313] 8 . 
11. Whitehead SJ, French J, Brookes MJ, Ford C, Gama R. Between-assay variability of faecal calprotectin enzyme-linked immunosorbent assay kits. Ann Clin Biochem. 2013;50(Pt 1):53?61.

12. Berthier S, Nguyen MVC, Baillet A, Hograindleur M-A, Paclet M-H, Polack B, et al. Molecular interface of S100A8 with cytochrome b558 and NADPH oxidase activation. PloS One. 2012;7(7):e40277.

13. Thewissen M, Damoiseaux J, van de Gaar J, Tervaert JWC. Neutrophils and T cells: bidirectional effects and functional interferences. Mol Immunol. 2011;48(15国16):2094回101.

14. Lee D-G, Woo J-W, Kwok S-K, Cho M-L, Park S-H. MRP8 promotes Th17 differentiation via upregulation of IL- 6 production by fibroblast-like synoviocytes in rheumatoid arthritis. Exp Mol Med. 2013;45:e20.

15. Lee Y, Jang S, Min J-K, Lee K, Sohn K-C, Lim J-S, et al. S100A8 and S100A9 are messengers in the crosstalk between epidermis and dermis modulating a psoriatic milieu in human skin. Biochem Biophys Res Commun. 2012;423(4):647?53.

16. Kane D, Roth J, Frosch M, Vogl T, Bresnihan B, FitzGerald O. Increased perivascular synovial membrane expression of myeloid-related proteins in psoriatic arthritis. Arthritis Rheum.

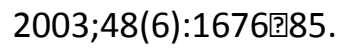

17. Abildtrup $M$, Kingsley GH, Scott DL. Calprotectin as a biomarker for rheumatoid arthritis: a systematic review. J Rheumatol. 2015;42(5):760?70.

18. Hammer HB, Fagerhol MK, Wien TN, Kvien TK. The soluble biomarker calprotectin (an S100 protein) is associated to ultrasonographic synovitis scores and is sensitive to change in patients with rheumatoid arthritis treated with adalimumab. Arthritis Res Ther. 2011;13(5):R178.

19. Hammer HB, $\varnothing$ degård $S$, Syversen SW, Landewé R, van der Heijde $D$, Uhlig $T$, et al. Calprotectin (a major S100 leucocyte protein) predicts 10-year radiographic progression in patients with rheumatoid arthritis. Ann Rheum Dis. 2010;69(1):150?4.

20. Jonsson MK, Sundlisæter NP, Nordal HH, Hammer HB, Aga A-B, Olsen IC, et al. Calprotectin as a marker of inflammation in patients with early rheumatoid arthritis. Ann Rheum Dis.

2017;76(12):2031?7.

21. Chevreau M, Paclet M-H, Romand X, Quesada J-L, Vittecoq O, Dieudé P, et al. Calprotectin is not independent from baseline erosion in predicting radiological progression in early rheumatoid arthritis. Comment on « Calprotectin as a marker of inflammation in patients with early rheumatoid arthritis » by Jonsson et al. Ann Rheum Dis. 2018;77(12):e84.

22. Hurnakova J, Hulejova H, Zavada J, Hanova P, Komarc M, Mann H, et al. Relationship between serum calprotectin (S100A8/9) and clinical, laboratory and ultrasound parameters of disease activity in rheumatoid arthritis: A large cohort study. PloS One. 2017;12(8):e0183420.

23. Nordal HH, Brokstad KA, Solheim M, Halse A-K, Kvien TK, Hammer HB. Calprotectin (S100A8/A9) has the strongest association with ultrasound-detected synovitis and predicts response to biologic treatment: results from a longitudinal study of patients with established rheumatoid arthritis. Arthritis Res Ther. 2017;19(1):3.

24. Inciarte-Mundo J, Ramirez J, Hernández MV, Ruiz-Esquide V, Cuervo A, Cabrera-Villalba SR, et al. Calprotectin and TNF trough serum levels identify power Doppler ultrasound synovitis in 
rheumatoid arthritis and psoriatic arthritis patients in remission or with low disease activity. Arthritis Res Ther. 2016;18(1):160.

25. Patro PS, Singh A, Misra R, Aggarwal A. Myeloid-related Protein $8 / 14$ Levels in Rheumatoid Arthritis: Marker of Disease Activity and Response to Methotrexate. J Rheumatol. 2016;43(4):731?7.

26. Obry A, Lequerré T, Hardouin J, Boyer O, Fardellone P, Philippe P, et al. Identification of S100A9 as biomarker of responsiveness to the methotrexate/etanercept combination in rheumatoid arthritis using a proteomic approach. PloS One. 2014;9(12):e115800.

27. Choi IY, Gerlag DM, Herenius MJ, Thurlings RM, Wijbrandts CA, Foell D, et al. MRP8/14 serum levels as a strong predictor of response to biological treatments in patients with rheumatoid arthritis. Ann Rheum Dis. 2015;74(3):499?505.

28. Tweehuysen $L$, den Broeder N, van Herwaarden N, Joosten $L A B$, van Lent $P L$, Vogl $T$, et al. Predictive value of serum calprotectin (S100A8/A9) for clinical response after starting or tapering anti-TNF treatment in patients with rheumatoid arthritis. RMD Open. 2018;4(1):e000654.

29. Smith SL, Plant D, Eyre S, Hyrich K, Morgan AW, Wilson AG, et al. The predictive value of serum S100A9 and response to etanercept is not confirmed in a large UK rheumatoid arthritis cohort. Rheumatol Oxf Engl. 2017;56(6):1019?24.

30. Rudwaleit M, van der Heijde D, Landewé R, Akkoc N, Brandt J, Chou CT, et al. The Assessment of SpondyloArthritis International Society classification criteria for peripheral spondyloarthritis and for spondyloarthritis in general. Ann Rheum Dis. 2011;70(1):25?31.

31. de Winter J, de Hooge $M$, van de Sande $M$, de Jong $H$, van Hoeven $L$, de Koning $A$, et al. Magnetic Resonance Imaging of the Sacroiliac Joints Indicating Sacroiliitis According to the Assessment of SpondyloArthritis international Society Definition in Healthy Individuals, Runners, and Women With Postpartum Back Pain. Arthritis Rheumatol Hoboken NJ. 2018;70(7):1042]8.

32. Baillet A, Gastaldi R, Ravey JN, Gaudin P. Bone Marrow Edema in the Sacroiliac JointDegenerative Sacroiliac Joint Disease Might Be More Likely Than Spondyloarthritis: Comment on the Article by Turina et al. Arthritis Rheumatol Hoboken NJ. 2017;69(5):1123]4.

33. Benhamou M, Gossec L, Dougados M. Clinical relevance of C-reactive protein in ankylosing spondylitis and evaluation of the NSAIDs/coxibs' treatment effect on C-reactive protein. Rheumatol Oxf Engl. 2010;49(3):536国1.

34. Hammer HB, Kvien TK, Glennås A, Melby K. A longitudinal study of calprotectin as an inflammatory marker in patients with reactive arthritis. Clin Exp Rheumatol. 1995;13(1):59?64.

35. Cypers H, Varkas G, Beeckman S, Debusschere K, Vogl T, Roth J, et al. Elevated calprotectin levels reveal bowel inflammation in spondyloarthritis. Ann Rheum Dis. 2016;75(7):1357]62.

36. Gupta L, Bhattacharya S, Agarwal V, Aggarwal A. Elevated levels of serum MRP8/14 in ankylosing spondylitis: associated with peripheral arthritis and active disease. Clin Rheumatol. 2016;35(12):3075国9. 
37. Huang J, Yin Z, Song G, Cui S, Jiang J, Zhang L. Discriminating Value of Calprotectin in Disease Activity and Progression of Nonradiographic Axial Spondyloarthritis and Ankylosing Spondylitis. Dis Markers. 2017;2017:7574147.

38. Klingberg E, Carlsten H, Hilme E, Hedberg M, Forsblad-d'Elia H. Calprotectin in ankylosing spondylitis--frequently elevated in feces, but normal in serum. Scand J Gastroenterol. 2012;47(4):435国44.

39. Turina MC, Sieper J, Yeremenko N, Conrad K, Haibel H, Rudwaleit M, et al. Calprotectin serum level is an independent marker for radiographic spinal progression in axial spondyloarthritis. Ann Rheum Dis. 2014;73(9):1746?8.

40. Turina MC, Yeremenko N, van Gaalen F, van Oosterhout M, Berg IJ, Ramonda R, et al. Serum inflammatory biomarkers fail to identify early axial spondyloarthritis: results from the SpondyloArthritis Caught Early (SPACE) cohort. RMD Open. 2017;3(1):e000319.

41. Grossi V, Infantino M, Manfredi M, Meacci F, Bellio E, Bellio V, et al. Serum calprotectin levels as a marker of arthritis: an italian experience. Curr Rheumatol Rev. 2016; DOI: $\underline{10.2174 / 1573397112666160331143000}$

42. Mosli MH, Zou G, Garg SK, Feagan SG, MacDonald JK, Chande N, et al. C-Reactive Protein, Fecal Calprotectin, and Stool Lactoferrin for Detection of Endoscopic Activity in Symptomatic Inflammatory Bowel Disease Patients: A Systematic Review and Meta-Analysis. Am J Gastroenterol. 2015;110(6):802]19; quiz 820.

43. Fukunaga S, Kuwaki K, Mitsuyama K, Takedatsu H, Yoshioka S, Yamasaki H, et al. Detection of calprotectin in inflammatory bowel disease: Fecal and serum levels and immunohistochemical localization. Int J Mol Med. 2018;41(1):107国18.

44. Turina MC, Yeremenko N, Paramarta JE, De Rycke L, Baeten D. Calprotectin (S100A8/9) as serum biomarker for clinical response in proof-of-concept trials in axial and peripheral spondyloarthritis. Arthritis Res Ther. 2014;16(4):413.

45. Baeten D, Baraliakos X, Braun J, Sieper J, Emery P, van der Heijde D, et al. Anti-interleukin-17A monoclonal antibody secukinumab in treatment of ankylosing spondylitis: a randomised,

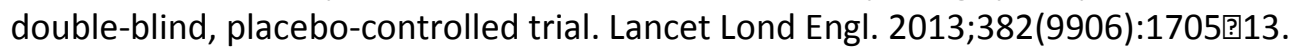

46. Madland TM, Larsen A, Brun JG. S100 proteins calprotectin and S100A12 are related to radiographic changes rather than disease activity in psoriatic arthritis with low disease activity. J Rheumatol. 2007;34(10):2089]92.

47. Frosch $M, \operatorname{Vog} \mid \mathrm{T}$, Seeliger $\mathrm{S}$, Wulffraat $\mathrm{N}$, Kuis $\mathrm{W}$, Viemann $\mathrm{D}$, et al. Expression of myeloidrelated proteins 8 and 14 in systemic-onset juvenile rheumatoid arthritis. Arthritis Rheum. 2003;48(9):2622?6.

48. Moncrieffe H, Ursu S, Holzinger D, Patrick F, Kassoumeri L, Wade A, et al. A subgroup of juvenile idiopathic arthritis patients who respond well to methotrexate are identified by the serum biomarker MRP8/14 protein. Rheumatol Oxf Engl. 2013;52(8):1467?76.

49. Falk RJ, Terrell RS, Charles LA, Jennette JC. Anti-neutrophil cytoplasmic autoantibodies induce neutrophils to degranulate and produce oxygen radicals in vitro. Proc Natl Acad Sci U S A. 1990;87(11):4115国9. 
50. Sangaletti S, Tripodo C, Chiodoni C, Guarnotta C, Cappetti B, Casalini P, et al. Neutrophil extracellular traps mediate transfer of cytoplasmic neutrophil antigens to myeloid dendritic cells toward ANCA induction and associated autoimmunity. Blood. 2012;120(15):3007?18.

51. Urban CF, Ermert D, Schmid M, Abu-Abed U, Goosmann C, Nacken W, et al. Neutrophil extracellular traps contain calprotectin, a cytosolic protein complex involved in host defense against Candida albicans. PLoS Pathog. 2009;5(10):e1000639.

52. Bjarnason I, Helgason KO, Geirsson AJ, Sigthorsson G, Reynisdottir I, Gudbjartsson D, et al. Subclinical intestinal inflammation and sacroiliac changes in relatives of patients with ankylosing spondylitis. Gastroenterology. 2003;125(6):1598?605.

53. Schultz H, Csernok E, Herlyn K, Reichel PH, Moosig F, Cornely OA, et al. ANCA against bactericidal/permeability-increasing protein, azurocidin, calprotectin and defensins in rheumatic and infectious diseases: prevalence and clinical associations. Clin Exp Rheumatol. 2003;21(6 Suppl 32):S117-120.

54. Pepper RJ, Hamour S, Chavele K-M, Todd SK, Rasmussen N, Flint S, et al. Leukocyte and serum S100A8/S100A9 expression reflects disease activity in ANCA-associated vasculitis and glomerulonephritis. Kidney Int. 2013;83(6):1150回8.

55. Pepper RJ, Wang H-H, Rajakaruna GK, Papakrivopoulou E, Vogl T, Pusey CD, et al. S100A8/A9 (calprotectin) is critical for development of glomerulonephritis and promotes inflammatory leukocyte-renal cell interactions. Am J Pathol. 2015;185(5):1264?74.

56. Pepper RJ, Draibe JB, Caplin B, Fervenza FC, Hoffman GS, Kallenberg CGM, et al. Association of Serum Calprotectin (S100A8/A9) Level With Disease Relapse in Proteinase 3-Antineutrophil Cytoplasmic Antibody-Associated Vasculitis. Arthritis Rheumatol Hoboken NJ. 2017;69(1):185]93.

57. Li SP, Goldman ND. Regulation of human C-reactive protein gene expression by two synergistic IL-6 responsive elements. Biochemistry. 1996;35(28):9060?]8.

58. Andrés Cerezo L, Mann H, Pecha O, Pleštilová L, Pavelka K, Vencovský J, et al. Decreases in serum levels of S100A8/9 (calprotectin) correlate with improvements in total swollen joint count in patients with recent-onset rheumatoid arthritis. Arthritis Res Ther. 2011;13(4):R122.

59. Levitova A, Hulejova H, Spiritovic M, Pavelka K, Senolt L, Husakova M. Clinical improvement and reduction in serum calprotectin levels after an intensive exercise programme for patients with ankylosing spondylitis and non-radiographic axial spondyloarthritis. Arthritis Res Ther. 2016;18(1):275. 


\section{Figure 1. Calprotectin enhances NADPH oxydase activity}

ROS production assay (Amplex red ${ }^{\mathrm{TM}}$ ) of pseudo-neutrophils (PMA-differenciated PLB985 at day 4) incubated with calprotectin or Phosphate Buffer Saline (PBS) during $1 \mathrm{H}$ at $37^{\circ} \mathrm{C}$. Relative Lumisence Unit: RLU

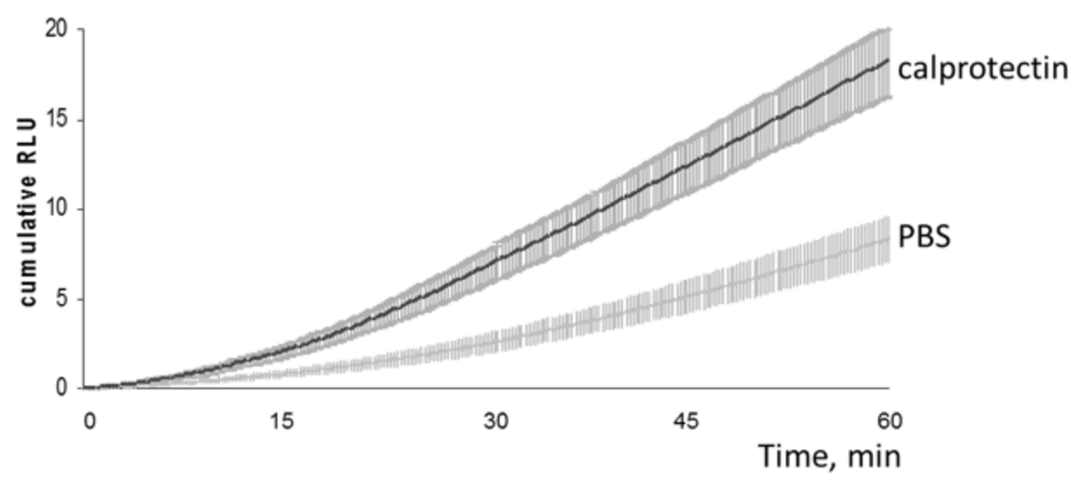


Table 1. Blood calprotectin correlates with disease activity in Rheumatoid arthritis.

\begin{tabular}{|c|c|c|c|c|c|c|}
\hline Study & CRP & ESR & DAS28 & SJC & $\begin{array}{l}\text { Blood } \\
\text { samples }\end{array}$ & Assay; Mean calprotectin level \\
\hline $\begin{array}{l}\text { Hammer HB et al. } \\
2010 \text { (19) }\end{array}$ & 0.59 & 0.67 & N/A & $\mathrm{N} / \mathrm{A}$ & $\begin{array}{l}\text { EDTA } \\
\text { plasma }\end{array}$ & $\begin{array}{l}\text { Home-made ELISA [67]; } \\
\text { Median 2.2, IQR (1.1-4.2) mg/I }\end{array}$ \\
\hline $\begin{array}{l}\text { Hammer HB et al. } \\
2007 \text { (8) }\end{array}$ & 0.57 & 0.50 & 0.55 & 0.49 & $\begin{array}{l}\text { EDTA } \\
\text { plasma }\end{array}$ & $\begin{array}{l}\text { Home-made ELISA [67]; } \\
\text { Median 1.8, Range }(0.3-8.7) \mathrm{mg} / \mathrm{l}\end{array}$ \\
\hline $\begin{array}{l}\text { Andres Cerezo L } \\
\text { et al. } 2011(58)\end{array}$ & 0.44 & $\mathrm{~N} / \mathrm{A}$ & 0.50 & 0.44 & Serum & $\begin{array}{l}\text { BÜHLMANN LABORATORIES AG, } \\
\text { SWITZERLAND; } \\
\text { Mean } \pm \text { SD } 5.99 \pm 0.88 \mathrm{mg} / \mathrm{L} \text { and } 1.92 \pm 1.16 \\
\mathrm{mg} / \mathrm{L} \text { respectively before and after } \\
\text { treatment }\end{array}$ \\
\hline $\begin{array}{l}\text { Jonsson MK et al. } \\
2017 \text { (20) }\end{array}$ & 0.66 & 0.50 & N/A & N/A & $\begin{array}{l}\text { EDTA } \\
\text { plasma }\end{array}$ & $\begin{array}{l}\text { CALPROLAB, NORWAY; } \\
\text { Median 1.05, IQR }(0.57,2.24) \mathrm{mg} / \mathrm{L}\end{array}$ \\
\hline $\begin{array}{l}\text { Hurnakova J et al. } \\
2017(22)\end{array}$ & 0.56 & 0.38 & 0.35 & N/A & Serum & $\begin{array}{l}\text { BÜHLMANN LABORATORIES AG, } \\
\text { SWITZERLAND; } \\
\text { Median (range) } 2.9(0.8-3.4) \text { and } 1.7 \text { (0.4- } \\
\text { 3.4) } \mu \mathrm{g} / \mathrm{mL}\end{array}$ \\
\hline $\begin{array}{l}\text { Nordal HH et al. } \\
2017 \text { (23) }\end{array}$ & N/A & $\mathrm{N} / \mathrm{A}$ & 0.49 & 0.47 & $\begin{array}{l}\text { EDTA } \\
\text { plasma }\end{array}$ & $\begin{array}{l}\text { CALPRO AS, NORWAY } \\
\text { Median 1.15, IQR }(0.70-1.95) \mathrm{mg} / \mathrm{L}\end{array}$ \\
\hline
\end{tabular}

CRP: C-reactive protein, ESR: Erythrocyte Sedimentation Rate, DAS28: Disease Activity Score of 28 joints, SJC: Swollen Joint Count, EDTA: Ethylenediaminetetraacetic acid, N/A not assessed, ELISA: Enzyme-Linked Immunosorbent Assay, IQR: Interquartile Range 25,75 percentile, SD: Standard Deviation. 
Table 2. Calprotectin as a biomarker of DMARD response in rheumatoid arthritis.

\begin{tabular}{|c|c|c|c|c|c|}
\hline Study & $\begin{array}{l}\text { Treatment ( } \mathrm{n} \\
\text { patients) }\end{array}$ & $\begin{array}{l}\text { Blood samples } \\
\text { (Assay) }\end{array}$ & $\begin{array}{l}\text { Calprotectin in } \\
\text { responders vs. non } \\
\text { responders }\end{array}$ & Threshold & Results \\
\hline $\begin{array}{l}\text { Nordal et al. } \\
2017 \text { (23) }\end{array}$ & $\begin{array}{l}\text { ETN 40\%, RTX } \\
22 \%, \text { TCZ 9\%, IFX } \\
9 \%, \text { CZP 8\%, ADA } \\
4 \%, \text { ABA 3\% }\end{array}$ & $\begin{array}{l}\text { Plasma } \\
\text { (ELISA } \\
\text { Calpronorway) }\end{array}$ & $\begin{array}{l}\text { Higher baseline value } \\
\text { of calprotectin in } \\
\text { EULAR responders at } 3 \\
\text { and } 12 \text { months }\end{array}$ & ND & ND \\
\hline $\begin{array}{l}\text { Patro et al. } \\
2016 \text { (25) }\end{array}$ & MTX & $\begin{array}{l}\text { Serum } \\
\text { (ELISA BMA } \\
\text { Biomed) }\end{array}$ & $\begin{array}{l}\text { Responders } \\
23.99 \mu \mathrm{g} / \mathrm{ml}, 95 \% \mathrm{Cl} \\
(15.39 ; 42.75) \\
\text { Non responders } \\
9.58 \mu \mathrm{g} / \mathrm{ml} 95 \% \mathrm{Cl} \\
(6.11 ; 24.93), \mathrm{p}=0.003\end{array}$ & $13.7 \mu \mathrm{g} / \mathrm{ml}$ & $\begin{array}{l}\text { AUC } 0.70 \\
95 \% \text { CI }[0.54 ; 0.86] \\
\text { Se } 79 \% \\
\text { Spe } 69 \% \\
\text { VPP } 73 \%\end{array}$ \\
\hline $\begin{array}{l}\text { Obry et al. } \\
2014 \text { (26) }\end{array}$ & MTX + ETN & $\begin{array}{l}\text { Serum } \\
\text { (ELISA } \\
\text { Cusabio) }\end{array}$ & $\begin{array}{l}\text { Responders } \\
510 \pm 130 \mathrm{ng} / \mathrm{ml} \\
\text { Non responders } \\
770 \pm 210 \mathrm{ng} / \mathrm{ml}, \mathrm{p}=0.32\end{array}$ & ND & ND \\
\hline \multirow[t]{3}{*}{$\begin{array}{l}\text { Choi et al. } \\
\text { 2015(27) }\end{array}$} & $\operatorname{ADA}(n=86)$ & $\begin{array}{l}\text { Serum } \\
\text { (ELISA) }\end{array}$ & $\begin{array}{l}\text { Responders } \\
1100 \mathrm{ng} / \mathrm{ml} \text {, IQR (711- } \\
1615) \\
\text { Non responders } \\
730 \mathrm{ng} / \mathrm{ml}, \text { IQR (575- } \\
1065), \mathrm{p}=0.010\end{array}$ & $995 \mathrm{ng} / \mathrm{ml}$ & $\begin{array}{l}\text { Se } 57 \% \\
\text { Spe } 71 \%\end{array}$ \\
\hline & IFX $(n=60)$ & $\begin{array}{l}\text { Serum } \\
\text { (ELISA) }\end{array}$ & $\begin{array}{l}\text { Responders } \\
2650 \mathrm{ng} / \mathrm{ml} \text {, IQR (1483- } \\
4120) \\
\text { Non responders } \\
1220 \mathrm{ng} / \mathrm{ml} \text {, IQR (1053- } \\
1533), \mathrm{p}=0.001\end{array}$ & $2027 \mathrm{ng} / \mathrm{ml}$ & $\begin{array}{l}\text { Se } 62 \% \\
\text { Spe } 86 \%\end{array}$ \\
\hline & $\operatorname{RTX}(n=24)$ & $\begin{array}{l}\text { Serum } \\
\text { (ELISA) }\end{array}$ & $\begin{array}{l}\text { Responders } \\
2811 \text { ng/ml, IQR (1945- } \\
4525) \\
\text { Non responders } \\
1050 \text { ng/ml, IQR (780- } \\
1290), \mathrm{p}<0.001\end{array}$ & $1665 \mathrm{ng} / \mathrm{ml}$ & $\begin{array}{l}\text { Spe } 91 \% \\
\text { Se } 85 \%\end{array}$ \\
\hline $\begin{array}{l}\text { Tweehuysen } \\
\text { et al. } \\
2018(28)\end{array}$ & $\begin{array}{l}\text { ADA }(n=50) \\
\text { ETN }(n=75)\end{array}$ & $\begin{array}{l}\text { Serum } \\
\text { (ELISA } \\
\text { University of } \\
\text { Münster) }\end{array}$ & $\begin{array}{l}\text { Responders } \\
985 \mathrm{ng} / \mathrm{ml}, 95 \% \mathrm{Cl}(558 ; \\
1417] \\
\text { Non responders } \\
645 \mathrm{ng} / \mathrm{ml}, 95 \% \mathrm{Cl}(415 ; \\
973), \mathrm{p}=0.04\end{array}$ & ND & $\begin{array}{l}\text { AUC } 0.61 \\
95 \% \mathrm{Cl}(0.50 ; 0.71)\end{array}$ \\
\hline $\begin{array}{l}\text { Smith et al. } \\
\text { 2017(29) }\end{array}$ & $\operatorname{ETN}(n=236)$ & $\begin{array}{l}\text { Serum } \\
\text { (ELISA } \\
\text { Cusabio, } \\
\text { China) }\end{array}$ & $\begin{array}{l}\text { Good responders } \\
165.5 \mathrm{ng} / \mathrm{ml} \\
\text { Moderate responders } \\
183.7 \mathrm{ng} / \mathrm{ml} \\
\text { Non responders } \\
183.8 \mathrm{ng} / \mathrm{ml}, \mathrm{p}=0.957\end{array}$ & ND & $\begin{array}{l}\text { OR } 1.0 \\
95 \% \mathrm{Cl}(0.99,1.00)\end{array}$ \\
\hline
\end{tabular}

ETN: etanercept, RTX: rituximab, TCZ: tocilizumab, IFX: infliximab, CZP: certolizumab, ADA: adalimumab, ABA: abatacept, MTX : methotrexate, ELISA: Enzyme-Linked Immunosorbent Assay, EULAR: European League Against Rheumatism, ND: Non Defined, 95\%Cl : 95\% Confidence interval, AUC : Area Under the Curve OR: Odds Ratio, Se : Sensitivity, Spe : Specificity, PPV : Positive Predictive Value, IQR : Interquartile Range 
Table 3. Serum calprotectin correlates weakly with disease activity in axial spondyloarthritis.

\begin{tabular}{|c|c|c|c|c|c|c|}
\hline Study & Disease & CRP & BASDAI & ASDAS-CRP & SJC & Structural \\
\hline $\begin{array}{l}\text { J.Huang et al. } \\
2017 \text { (37) }\end{array}$ & $\begin{array}{l}\text { AS mNY+ } \\
\text { Nr-axSpA ASAS + }\end{array}$ & $0.431^{* * *}$ & $0.481^{* * *}$ & $0.378^{* * *}$ & N/A & $\begin{array}{l}\text { SPARCC-SI } \\
0.405^{* * *} \\
\text { mSASSS } \\
-0.033\end{array}$ \\
\hline $\begin{array}{l}\text { Turina et al. } \\
2014 \text { (39) }\end{array}$ & $\begin{array}{l}\text { AS mNY + or ax SpA } \\
\text { with one } \\
\text { syndesmophyte }\end{array}$ & $0.382^{* * *}$ & $\mathrm{~N} / \mathrm{A}$ & $\mathrm{N} / \mathrm{A}$ & $\mathrm{N} / \mathrm{A}$ & N/A \\
\hline $\begin{array}{l}\text { Cypers et al. } \\
2016 \text { (35) }\end{array}$ & $\begin{array}{l}\text { axSpA ASAS + } \\
\text { or } \\
\text { SpA peripheral } \\
\text { ASAS+ }\end{array}$ & $0.386^{* * *}$ & NS & $\mathrm{N} / \mathrm{A}$ & NS & $\mathrm{N} / \mathrm{A}$ \\
\hline $\begin{array}{l}\text { Gupta et al. } \\
2016(36)\end{array}$ & axSpA ASAS + & $0.279^{* *}$ & $0.15^{\mathrm{NS}}$ & $0.23^{* *}$ & $0.38^{* *}$ & $\mathrm{~N} / \mathrm{A}$ \\
\hline $\begin{array}{l}\text { Oktayoglu et } \\
\text { al. } 2014 \text { (9) }\end{array}$ & AS mNY + & $-0.234^{\mathrm{NS}}$ & $-0.278^{\mathrm{NS}}$ & $0.243^{\mathrm{NS}}$ & N/A & N/A \\
\hline $\begin{array}{l}\text { Klingberg et } \\
\text { al. } 2012 \text { (38) }\end{array}$ & AS mNY + & $0.337^{* * *}$ & NS & $0.162^{\mathrm{NS}}$ & N/A & N/A \\
\hline $\begin{array}{l}\text { Turina et al. } \\
2014 \text { (44) }\end{array}$ & SpA ESSG + & $0.646^{*}$ & $0.325^{*}$ & $\mathrm{~N} / \mathrm{A}$ & $\mathrm{N} / \mathrm{A}$ & $\mathrm{N} / \mathrm{A}$ \\
\hline
\end{tabular}

CRP: C-reactive protein, BASDAI: Bath Ankylosing Spondylitis Disease Activity Index, ASDAS-CRP: Ankylosing Spondylitis Disease Activity Score with CRP, SJC : Swollen Joint Count, AS: Ankylosing Spondylitis, mNY+: patient fulfilling modified New York criteria, SpA: spondyloarthrites, axSpA: axial Spondyloarthritis, Nr-ax SpA: Non radiological axial Spondyloarthritis, ASAS+: patient fulfilling Assessment of Spondyloarthritis international Society, SPARCC-SI: Spondyloarthritis Research Consortium of Canada Sacroiliac joint score, mSASSS: modified Stoke Ankylosing Spondylitis Spinal Score, ESSG : patient fulfilling European Spondylarthropathy Study Group criteria, N/A: Not Assessed, NS: Not Significant. ${ }^{*} p<0.05,{ }^{* *} p<0.01,{ }^{* * *} p<0.001$ 
Table 4. Serum calprotectin level assessed with different ELISA kit in axial spondyloarthritis and ankylosing

\begin{tabular}{|c|c|c|c|c|c|c|c|c|c|}
\hline Study & ELISA Kit & Disease & Patients (n) & \begin{tabular}{|l} 
Male \\
(\%)
\end{tabular} & $\begin{array}{l}\text { Age, } \\
\text { years }\end{array}$ & \begin{tabular}{|l|} 
Disease \\
duration, \\
years
\end{tabular} & HLA B27 (\%) & BASDAI & $\begin{array}{l}\text { Serum calprotectin } \\
(\mathrm{mg} / \mathrm{L})\end{array}$ \\
\hline \begin{tabular}{|c|} 
Turina $e t$ \\
$a l .2017$ \\
$(40) 00 / 00 /$ \\
0000 \\
$00: 00: 00$ \\
\end{tabular} & \multirow{3}{*}{$\begin{array}{c}\text { HYCULT BIOTECH, } \\
\text { the Netherlands } \\
\S\end{array}$} & axSpA ASAS + & 119 & 51 & $32 \pm 8$ & $1.1 \pm 0.6$ & 86 & $3.9 \pm 2.4$ & $0.294(0.214-0.367)$ \\
\hline $\begin{array}{c}\text { Turina et } \\
\text { al.2014 } \\
\text { (39) }\end{array}$ & & $\begin{array}{c}\text { AS mNY + } \\
\text { or } \\
\text { axSpA with } \\
\text { syndesmophyte }\end{array}$ & 76 & 66 & $38 \pm 12$ & $4.6 \pm 2.8$ & 82 & ND & $\begin{array}{c}\text { mSASSS worsening } \\
0.68 \pm 0.21 \\
\text { without mSASSS } \\
\text { worsening } \\
0.48 \pm 0.26\end{array}$ \\
\hline \begin{tabular}{|c|} 
Turina et \\
al.2014 \\
$(44)$
\end{tabular} & & SpA ESSG + & 37 & 68 & $\begin{array}{c}48 \\
(29- \\
66)\end{array}$ & $\begin{array}{c}8.0(2.0- \\
34.0)\end{array}$ & 55 & $\begin{array}{c}5.3 \\
(2.8- \\
8.6)\end{array}$ & $\begin{array}{c}\mathrm{SpA} \\
1.760 \pm 0.13\end{array}$ \\
\hline $\begin{array}{c}\text { Huang et } \\
\text { al. } 2017 \\
\text { (37) }\end{array}$ & $\begin{array}{c}\text { CUSABIO BIOTECH } \\
\text { Co, China }\end{array}$ & $\begin{array}{c}\text { AS mNY+ } \\
\text { or } \\
\text { axSpA ASAS + }\end{array}$ & $\begin{array}{l}53 \mathrm{AS}, \\
59 \mathrm{Nr}-\mathrm{axSpA}\end{array}$ & 66 & $\begin{array}{c}\text { AS } \\
32 \pm 8 \\
\mathrm{Nr}- \\
\text { axSpA } \\
34 \pm 8\end{array}$ & $\begin{array}{c}\text { AS 5.2 } \pm 3.6 \\
\text { Nr-axSpA } \\
5.0 \pm 4.1\end{array}$ & $\begin{array}{c}\text { AS } 86.7 \\
\text { Nr-axSpA: } \\
81.3\end{array}$ & $\begin{array}{c}\text { AS } \\
3.4 \pm 1.1 \\
\mathrm{Nr}- \\
\text { axSpA } \\
4.2 \pm 1.4\end{array}$ & $\begin{array}{c}\text { AS } \\
0,015 \pm 0,007 \\
\mathrm{Nr}-\mathrm{axSpA} \\
0.018 \pm 0.009\end{array}$ \\
\hline $\begin{array}{c}\text { Cypers et } \\
\text { al.2016 } \\
(35)\end{array}$ & \multirow[b]{2}{*}{$\begin{array}{c}\text { BÜHLMANN } \\
\text { LABORATORIES } \\
\text { AG, } \\
\text { Schoenenbuch, } \\
\text { Switzerland §§ }\end{array}$} & $\begin{array}{c}\text { axSpA ASAS + } \\
\text { or } \\
\text { peripheral SpA } \\
\text { ASAS + }\end{array}$ & $\begin{array}{c}45 \mathrm{AS}, \\
59 \mathrm{Nr}-\mathrm{ax} \\
\text { SpA, } \\
\text { 21peripheral } \\
\text { SpA ASAS + }\end{array}$ & ND & ND & ND & $\begin{array}{c}\text { AS 86, } \\
\text { Nr-axSpA 70, } \\
\text { peripheral } \\
\text { SpA } 55\end{array}$ & ND & $\begin{array}{c}\text { Without bowel } \\
\text { inflammation } 3.022 \\
(0.741-10.106), \\
\text { With bowel } \\
\text { inflammation } \\
3.948(0.782- \\
17.246)\end{array}$ \\
\hline $\begin{array}{c}\text { Levitova et } \\
\text { al.2016 } \\
(59)\end{array}$ & & axSpA ASAS + & 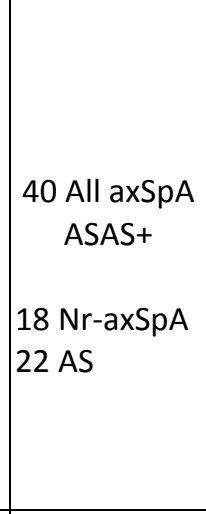 & $\begin{array}{c}\text { All } \\
\text { axSpA } \\
\text { ASAS } \\
+ \\
67.5, \\
\text { Nr- } \\
\text { axSpA } \\
50, \\
\text { AS } 82\end{array}$ & $\begin{array}{c}\text { All } \\
\text { axSpA } \\
\text { ASAS } \\
+ \\
37 \pm 1 \\
\mathrm{Nr}- \\
\operatorname{axSpA} \\
37 \pm 2 \\
\text { AS } \\
37 \pm 1\end{array}$ & $\begin{array}{c}\text { All axSpA } \\
\text { ASAS+ } \\
9.9 \pm 1.3 \\
\text { Nr-axSpA } \\
7.1 \pm 2.2 \\
\text { AS } \\
12.3 \pm 1\end{array}$ & $\begin{array}{c}\text { All axSpA } \\
\text { ASAS+ } \\
90.0 \\
\text { Nr-axSpA } 89 \\
\text { AS 91 }\end{array}$ & $\begin{array}{c}\text { All } \\
\text { axSpA } \\
\text { ASAS+ } \\
2.78 \pm \\
0.31 \\
\mathrm{Nr}- \\
\text { axSpA } \\
2.98 \pm \\
0.28 \\
\text { AS } \\
2.63 \pm \\
0.35 \\
\end{array}$ & $\begin{array}{c}\text { All axSpA ASAS+ } \\
2.408 \pm 0.183 \\
\text { Nr-axSpA } \\
2.379 \pm 0.243 \\
\text { AS } \\
2.430 \pm 0.270\end{array}$ \\
\hline $\begin{array}{c}\text { Gupta et } \\
\text { al. } 2016 \\
\text { (36) }\end{array}$ & $\begin{array}{l}\text { BIOLEGEND, } \\
\text { USA § }\end{array}$ & axSpA ASAS + & 99 & 91 & $\begin{array}{c}30 \\
(16- \\
62)\end{array}$ & $\begin{array}{c}6.0(0.3- \\
30.0)\end{array}$ & 90 & ND & 34.1 (17.94-264.58) \\
\hline \begin{tabular}{|c|}
$\begin{array}{c}\text { Oktayoglu } \\
\text { et al.2014 } \\
(9)\end{array}$ \\
\end{tabular} & \multirow{2}{*}{$\begin{array}{l}\text { IMMUNDIAGNOS } \\
\text { TIK, Germany }\end{array}$} & AS $\mathrm{mNY}+$ & 31 & 74 & $\begin{array}{c}29.7 \pm \\
8.1\end{array}$ & $5.5 \pm 4.5$ & 71 & $4.2 \pm 1.7$ & $0.819 \pm 0.553$ \\
\hline \begin{tabular}{|c|} 
Klingberg \\
et al. 2012 \\
$(38)$
\end{tabular} & & AS mNY+ & 205 & 57 & $50 \pm 13$ & $24 \pm 13$ & 87 & $3.6 \pm 2.1$ & $0.660 \pm 0.860$ \\
\hline
\end{tabular}

spondylitis.

ELISA: Enzyme-Linked Immunosorbent Assay, HLA B27: Human Leukocyte Antigen B27, BASDAI: Bath Ankylosing Spondylitis Disease Activity Index, AS: Ankylosing Spondylitis, mNY: modified New York criteria, AxSpA: Axial Spondyloarthritis, Nr-axSpA: Non radiological axial Spondyloarthritis, ASAS: Assessment of Spondyloarthritis international Society criteria, mSASSS: modified Stoke Ankylosing Spondylitis Spinal Score, ESSG: European 
Spondylarthropathy Study Group criteria, ND: Not Defined. Continuous data are presented as mean \pm standard deviation or median (range). § Research use only ELISA kit; §§ In vitro diagnosis ELISA kit 